\title{
Crowning Moments
}

\section{Transformative populist use of the media and the case of Carl I. Hagen}

\section{Hilmar Mjelde}

Department of Information Science and Media Studies, University of Bergen, Norway

\begin{abstract}
This article presents the concept of a "crowning moment" and proposes an explanation for the media-savviness of many populist leaders - an under-theorised ability often referred to in existing research. A crowning moment is an instance in which populist leaders take advantage of opportunities that arise in their surroundings to achieve a or multiple major policy, political and/or personal goals through skilful use of the media that earns them recognition as savvy politicians. The concept is exemplified through an analysis of Norwegian Progress Party leader Carl I. Hagen's role in the 1987 no-confidence motion against the Labour Party government. Stoking up and exploiting media interest in dramatic fashion, Hagen managed to redefine himself as a national political leader and made his party appear responsible.
\end{abstract}

Keywords: crowning moment, populist use of the media, Carl I. Hagen, populism, strategical media use

\section{Introduction}

Existing research finds, first, that the media facilitate populism, as there is overlap between populist communication and media production styles (e.g. tabloidisation) (Blumler \& Kavanagh, 1999; Esser et al., 2017; Mazzoleni, 2008, 2014; Manucci, 2017; Mudde, 2004). Second, the media-savviness of populist leaders such as Jörg Haider, Carl I. Hagen, Geert Wilders, Silvio Berlusconi, Marine Le Pen, Nigel Farage and Donald Trump is frequently cited as a key factor in their political rise, even though this ability has not been much theorised (Boczkowski \& Papacharissi, 2018; Esser et al., 2017; Manucci, 2017; Mazzoleni, 2008, 2014).

This article adds to the first finding by developing the concept of a "crowning moment". The concept denotes an instance in which populists take advantage of opportunities that arise in their surroundings to achieve one or multiple policy, political and/or personal goal(s) through skilful use of the media that earns them recognition as savvy politicians. Previously regarded primarily as outsiders, they are, after the "crowning", seen as something of a mastermind of the political game, with a capacity for strategising

Mjelde, Hilmar (2019) Crowning moments: Transformative populist use of the media and the case of Carl I. Hagen in Nordicom Review 40 (2019) 1, pp. 91-103. doi:10.2478/nor-2019-0005. 
and manoeuvring that is exemplary in terms of pure political skill. Even if they are still outsiders ideologically and rhetorically, they have become insiders in terms of excelling at the political game. The article adds to the second finding - the media-savviness of many populist leaders - by proposing that populism is inherently likely to produce leaders willing and able to leverage the media for their own benefit.

The concept of a crowning moment is similar to the concepts of "critical junctures" and "political opportunity structures" in political science and political sociology in its focus on favourable circumstances creating opportunities for change (for overviews, see Capoccia, 2016 and Giugni, 2009). However, while these general concepts tend to focus on the development of institutions and collective actors such as social movements, the concept of a crowning moment is more specific in that it is only concerned with the transformative effects of individual populists' use of the media, for that specific individual, within a favourable context.

The Progress Party is the oldest successful right-wing populist party in the Nordic region (Jungar \& Jupskås, 2014; Jupskås, 2015), and given (former) party leader Carl I. Hagen's dominant position within the party - for three decades, the public image of the party was closely linked to that of Hagen - the party, Hagen himself, and the episode are representative of West-European populist radical right parties and their reliance on charismatic, media-savvy leaders (see Mazzoleni, 2008, 2014). It is thus an appropriate case for developing a concept that can guide future studies of the rise of other populist leaders, and it effectively shows how a crowning moment can play out. During the 1987 no-confidence motion against the Labour Party government, Hagen skilfully executed his media-centred plan so that the week-long drama, which kept the country in suspense, played to his advantage. By successfully framing the issue at hand - a conflict between the government and the farmers - as a matter of fiscal responsibility, Hagen's party earned some much-needed credibility as a serious and responsible actor, with Hagen himself winning much praise for his gambit, thus elevating him personally, too.

Next, I review previous theories on populism and the media. After a methodological note, I define and explain the concept of a crowning moment and apply it to the case of Hagen. The conclusion discusses the implications of the study.

\section{Theory review: populism and the mediatization of politics}

The study of populism through the media encompasses two separate strands of research: populism as a concept, and the ways in which it connects to the media. Although populism can be conceptualised "as an ideology, as a discursive style, and a form of political mobilization" (Gidron \& Bonikowski, 2013: 5; see also Canovan, 1999; Zaslove, 2008), most of the existing literature treats populism as either an ideology or as a style of communication. There is general agreement that the privileging and extolling of "the people" and anti-elitism are the core attributes, with the exclusion of various out-groups, especially immigrants, as an additional defining characteristic. For example, in Mudde's (2004: 543) influential definition, populism is "an ideology that considers society to be ultimately separated into two homogeneous and antagonistic groups, 'the pure people' versus 'the corrupt elite', and which argues that politics should be an expression of the volonté générale (general will) of the people". Jagers and Walgrave (2007: 322), on the other hand, consider populism to be a political communication style that "refers to the 
people, vents anti-establishment ideas and simultaneously excludes certain population categories".

Regarding the links between populism and the media, Mazzoleni (2014: 49), who argues that (political) "populism is largely a communicative phenomenon", stresses that it "is strongly correlated with media populism (with its popular and ideological basis)". There are multiple approaches to studying the relationship between populism and the media, ranging from the mediatization of politics, populism by the media themselves, populism through online communication, populist citizen journalism to considerations of the possible deleterious effects of populism broadcasted by the media on democracy (Esser et al., 2017; Manucci, 2017; Mazzoleni, 2014). This article focuses on the mediatization of politics and populism, or what Esser and colleagues (2017: 4) ${ }^{1}$ refer to as "populism through the media". The mediatization of politics is a subtopic of the much wider concept of mediatization, which "refers to a social change process in which media have become increasingly influential in and deeply integrated into different spheres of society" (Strömbäck \& Esser, 2014: 3; see also Asp, 1986; Hjarvard, 2008; Lundby, 2009). ${ }^{2}$ Asp (1986: 359) defines it as a process where "a political system to a high degree is influenced by and adjusted to the demands of the mass media in their coverage of politics". The media's influence on politics, in particular campaigning, has also received considerable attention in political science and party studies (see Farrell, 2006; Semetko, 2006). The arrival of television and public opinion polls in the 1950s signalled the start of "parties in the media age" (Semetko, 2006: 515), in which parties communicate with voters primarily through the mass media. Wiesendahl (2009: 38) characterises the orientation towards television as a "Copernican turn" in modern campaigning, which in turn has become a permanent feature of politics (Blumenthal, 1982). Strömbäck and Esser (2014: 15), who conceive of four dimensions of the overall concept, the mediatization of politics (the media as information source; media autonomy; media practices; political practices), also note that mediatization can be expected to impact the public partisan-political process in particular, which is about "the processes of garnering support for one's candidacy, party or political programme". They stress, however, that "mediatization is not a linear and unidirectional process with a uniform influence across political actors and institutions within or across countries" (Strömbäck \& Esser, 2014: 20).

It is this arena that populists may be particularly suited to compete in. In what Blumler and Kavanagh (1999) describe as the "third age of political communication", marketisation and tabloidisation have made infotainment, politainment, sensationalism, superficiality and personalisation defining features of contemporary mass media. Charismatic, flamboyant, media-savvy populists, with their simple and polarising rhetoric, thrive in this environment (Manucci, 2017; Mazzoleni, 2008, 2014). According to Esser and colleagues (2017: 4-5), a stylistic "congruence between media logic and political populism" means that the media easily accommodate populist discourse, as "[c]harismatic leaders, harsh rhetoric, and stirring issues hit all the right keys of newsworthiness". Their amplification of the populist message amounts to "media complicity", according to Mazzoleni (2008: 50), meaning that “[w]hen the media report on these actors' slogans, arguments, and ideological perspectives, they heighten their public visibility and perceived legitimacy" (Esser et al., 2017: 4). Thus, the media are one of several "external supply-side" factors that constitute the "political opportunity structures" within which populists succeed or fail (Mudde, 2007: 232, 248-53). 


\section{A methodological note}

The purpose of this analysis is to develop the concept of a crowning moment semantically; the article primarily defines it (see Collier \& Mahon, 1993; Goertz, 2006; Sartori, 1970). I derived the concept during an inductive analysis of events surrounding the 1987 no-confidence motion against the Norwegian government, and Carl I. Hagen's role in it. My approach is similar to Thomas' (2006: 238) use of inductive analysis, which he defines as "approaches that primarily use detailed readings of raw data to derive concepts, themes, or a model through interpretations made from the raw data by an evaluator or researcher". The material used was, first, three books and an op-ed which detail the course of events (Hagen's own 2007 biography; an unauthorised 2006 biography about Hagen by journalist Elisabeth Skarsbø Moen; the [authorised] 1998 biography of the Progress Party's first 25 years; a 2014 op-ed by social scientist Hilmar Rommetvedt) and, second, a set of newspaper articles mostly covering Hagen's TV appearance on 11 June.

\section{Crowning moments: transformative populist use of the media}

The mediatization of politics is a general trend that affects political actors and institutions in Western societies to varying degrees, and we should therefore expect considerable empirical variation with respect to different cases. Political parties, including populist actors, operate within various and varying constraints that affect what they can and will do. Accounting for and assessing the effects of this interplay between various external and internal supply-side factors, with respect to the opportunities they create for populists, is beyond the scope of this article. The point of departure here is the assumption that within any type of political setting, a perceptive and savvy populist will recognise favourable circumstances when they are present and make the most of them to achieve his/her goal.

My concern here is with occasions when populist leaders use the media in a transformative way that I characterise as a "crowning moment". The concept denotes an instance in which populists take advantage of opportunities that arise in their surroundings to achieve one or multiple major policy, political and/or personal goal(s) through skilful use of the media that earns them recognition as savvy politicians. In proposing this concept, I have drawn inspiration from three distinct scholarly literatures, two of which are partially related. First, within the American presidency literature, George Edwards' thesis of presidential leadership holds that presidents' ability to lead is highly constraint-sensitive and context-dependent:

(...) successful presidents facilitate change by recognizing opportunities in their environments and fashioning strategies and tactics to exploit them. In other words, presidents who are successful in obtaining support for their agendas have to evaluate the opportunities for change in their environments carefully and orchestrate existing and potential support skilfully. (Edwards, 2012:2)

The proposition that a favourable configuration of environmental forces can create a window of opportunity for some actor to accomplish some or multiple goals can be applied to a variety of settings, as it merely highlights the potential for action when political opportunity is matched by political skill. 
Second, Strömbäck and Esser's (2014) conceptualisation of the mediatization of politics explains why the media may be a major facilitator when the right political opportunity presents itself. Specifically, the media, which are the most important information source for the public, and because they are independent, have their own standards for newsworthiness that attention-seeking political actors and institutions adapt to. The media-savvy populist can thus cater to the media's appetite for conflict and drama and leverage media coverage to achieve some specific goal. Moreover, the media can confer authority upon someone through their coverage (Herbst, 2003).

Third, Pedersen's theory of party lifespans (1982) and Mazzoleni's (2008) three phases of populist-media relations imply that parties have different priorities at different points in time, and that the potential for "partnering" with the media may be greatest in "the insurgent phase", when the populists "stage controversial events, engage in verbal extremism and fiercely attack government policies (for example, on immigration, taxes and social welfare)" (Mazzoleni, 2008: 60).

The idea of a crowning moment suggests that politics is not awash with opportunities for a breakout moment. Populists, including those who excel at attracting media attention, must usually invest considerable time and effort in conventional, unspectacular partisan-political activities, such as organisation-building, in order to have long-term influence on public policy, lest they disappear again after an initial electoral breakthrough (Harmel et al., 2018; Mudde, 2007). While these long-term and time-consuming undertakings are a tall order for any party leader, they are particularly challenging for populists. Populism is anti-establishment - a protest against the political, economic and cultural elites. Furthermore, it is a "thin ideology" (Freeden, 1998; Mudde, 2004) that eschews detail-rich policy programmes in favour of sweeping, often slogan-driven policy solutions centring on the populist leader's supposedly exceptional leadership abilities. Populists are also often very sceptical of party organisations and prefer unmediated decision-making by a strong leader. Mogens Glistrup, for example, opposed a party organisation because he did not want to be bothered with it, while Anders Lange saw party organisations as the mode of establishment politics (Harmel et al., 2018). Populists' conflict-oriented rhetoric further complicates coalition-building. For these reasons, populists have excelled in opposition but struggled in government, which requires moderation and concessions (Heinisch, 2003).

Sometimes, however, an opportunity comes along where the populist gets a chance to move the ball far down the field. A crowning moment is thus when he/she has a breakout moment and accomplishes something transformative that would otherwise take much longer time, or perhaps even be impossible, had he/she not seized that opportunity. Populists tend to be "clever newsmakers" who get the media's attention "via press conferences, theatrical events, photo-opportunities, or by making inflammatory statements" (Mazzoleni, 2008: 55-56) to the extent that they may become "a political 'pop star' or "media-icon"' (Mazzoleni, 2008: 56). To be sure, these skills will at times reinforce some of the shortcomings discussed above. For example, an outrageous statement in a TV interview may reinforce the public perception of a particular populist as divisive and unfit for high office. On the other hand, a populist could also use a highly publicised media appearance to improve both his/her public image and the image amongst fellow politicians by convincing them that he/she is a force to be reckoned with and even someone they can work with. 
Populists' apparent ability to attract media attention begs the question of what inherent qualities they possess that other politicians do not, or seemingly not to the same degree. I suggest that certain aspects of populism are conducive to getting media attention. The preference for a strong leader is likely to attract candidates for such leadership who, to some degree, are "natural" leaders. Getting a following shows the populist's ability to lead in the sense of taking action and inspiring others, and requires perceptiveness in terms of sensing what will trigger a response from others, and, probably, a predilection for personal attention. The perceptiveness appears to either extend to the media and their logic or lead to the realisation that he or she needs to learn how the media operate, because they can provide him or her with a megaphone. Combined with Manichean populist ideology/rhetoric, by which the populist casts him- or herself as a contrarian figure, all this should translate into an ability and willingness to say and do things that appeal to the media's taste for conflict and drama, especially those media outlets that engage in populism themselves (see e.g. Esser et al., 2017). Moreover, personal charisma is a quality that, when added to the aforementioned ones, can help vault the populist leader to the forefront of national politics, even though it may not be decisive. I propose that these qualities explain populists" "special ability to make headlines and appear on breaking news, depending on the particular mood of the country" (Mazzoleni, 2008: 56). Paradoxically, however, crowning moments can make populists less anti-establishment, since they turn the populists into leading actors within the system that they criticise. Understood this way, crowning moments are unique to populists.

What counts as transformative must be assessed on a case-by-case basis; the criterium must be that the populist is able to harness a confluence of factors in the political and media environments into making them work for him/her, thus enabling the populist to achieve one or multiple major policy, political and/or personal goal(s) in a way that transform(s) his/her status. In order to assess if a certain chain of events amounts to a crowning moment, the researcher therefore needs intimate knowledge of the case at hand. Not all populists will get such an opportunity or be able to recognise and exploit it. Moreover, some will achieve long-term success without having experienced a particular crowning moment. However, when a populist takes centre stage and manages to come out ahead in a high stakes political situation that is playing out under the media glare, it might be a crowning moment. Figure 1 illustrates the dynamics of a crowning moment.

In Figure 1, a political opportunity is any major event or political development to which political actors, in a given political system, must respond. Those involved perceive that something important is at stake and attempt to influence the ensuing process in order to protect or advance their own interests. Such an opportunity could for example be a brewing conflict within a party, an unexpected election result, the death or resignation of an important political leader or a government crisis.

A media opportunity denotes extraordinary media interest in an event or political development, including possible consequences and the responses of the involved political actors. This could, for example, be continual coverage of a tragic accident that national politicians must tackle, and situations when the media and the political opposition seek to hold the government accountable. Depending on how political actors respond, both the political opportunity and media opportunity thus hold the potential to have important consequences. As one of the political actors at the centre of attention, or with the opportunity and ability to insert him- or herself into the situation, the populist leader weighs 
Figure 1. A theoretical model of a crowning moment

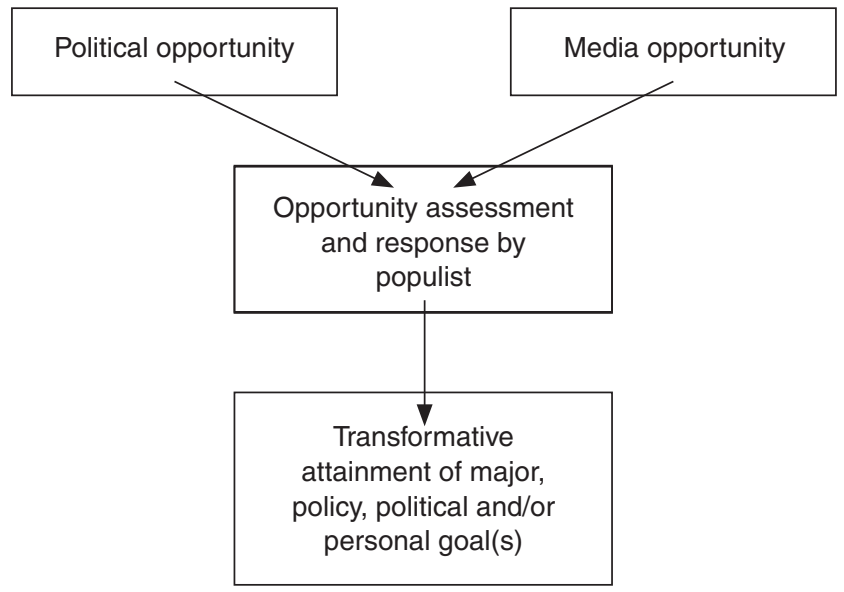

the options and ultimately settles on the course of action that is believed to serve one or multiple major policy, political and/or personal goal(s) in a transformative way. If, for example, a major corruption scandal involving prominent politicians is unearthed, a populist may be able to craft a line of attack against the establishment that shapes the media narrative and resonates widely within the electorate. As a result, the populist may make a major electoral breakthrough, provide the impetus for significant policy reform or be seen as a serious contender for high office.

In the next section, the concept of a crowning moment is applied in the analysis of the events surrounding the 1987 no-confidence motion against the Norwegian government. The analysis shows how Hagen very skilfully used the situation to advance his party's political interests and transform his personal image.

\section{The case of Carl I. Hagen and the 1987 no-confidence motion}

The Progress Party was founded in 1973 by the 69-year old dog kennel owner Anders Lange in an Oslo movie theatre. "Anders Lange's party for a strong reduction in taxes, fees, and public intervention", renamed Fremskrittspartiet (The Progress Party) in 1977, had many of the characteristics of populism: personalised leadership, an antiestablishment attitude and a party programme emphasising what it was against. During Carl I. Hagen's 28 years (1978-2006) at the helm of the party, a rather conventional, mass-party like party organisation was combined with de facto personalised leadership. While the party became less strident in its view of the state, it retained its populist view of representative democracy and espoused anti-immigrant views (Svåsand, 2002). ${ }^{3}$ It has also kept its slogan "For regular people" (For folk flest). As the face of the party, Hagen was often called the most media-savvy politician in the country, and his TV appearances and rhetoric have been the focus of academic studies (Johansen, 2002; Kjeldsen, 2002); notably, Erik Solheim, a former leader of the Socialist Left Party, has conceded that he copied Hagen's style (Todal, 2003). It was Hagen's manoeuvring in the 1987 no-confidence motion against the government that earned Hagen the unofficial title of the most media-savvy politician in the country. 


\section{The political and media opportunity}

In the 1985 parliamentary election, the Progress Party, still a young party that was not yet institutionalised, won only two seats, down from four in the previous period. ${ }^{4}$ On the other hand, with the overall election result, the party now became the swing vote in the parliament, wielding significant blackmailing power in the Storting. It could choose to support either the centre-right coalition government of the Conservative Party, the Christian Democrats, and the Centre Party, or the Labour Party, Norway's largest party and the only government alternative. In May of 1986, Hagen voted against the centre-right coalition government in a vote of no confidence and a Labour Party government replaced it.

In the spring of 1987, the Conservative Party was eager to get back into government and looking for an opportunity in parliament to force the Labour Party government to resign through a no-confidence motion together with its two former coalition partners. They agreed to do it over the government's handling of the annual negotiations with the farmers' unions, which led to 10,000 protesting farmers marching in Oslo (Rommetvedt, 2014). Pressured by the agrarian Centre Party, the Conservative Party and the Christian Democrats agreed to increase the subventions to the farmers beyond what the government had offered. However, they needed the Progress Party's two votes and apparently assumed that Hagen would prefer a new centre-right government and support them, even though the Progress Party was known to favour a reduction in such subsidies. After all, Hagen had himself introduced unsuccessful no-confidence motions against the Labour Party government in May and October of 1986, and voted for another unsuccessful noconfidence motion in May of 1987 (Iversen, 1998: 100; Moen, 2006: 157;).

In the post-war era, only two Norwegian governments $(1963,1986)$ had fallen after losing a confidence vote. Any confidence vote that stands a chance of succeeding is therefore a major political and media event. In 1987, the Norwegian Broadcasting Corporation (NBC) still enjoyed a TV monopoly. ${ }^{5}$ The radio monopoly fell in 1981, when the first local radio stations emerged (Sandnes \& Tørdal, 2018), but the NBC was, in practice, still a monopoly broadcaster in 1987. By contrast, there were two major broadsheets and two major tabloids, in addition to numerous other national and regional newspapers. It was Hagen's deliberate strategy to stoke up public interest in how he and the Progress Party would ultimately vote, and his strategic use of the NBC, that turned the affair into a media drama.

\section{Carl I. Hagen's assessment and response}

When the Conservative Party, the Christian Democrats and the Centre Party announced their plan for a no-confidence vote over the agricultural negotiations, on which the Storting would vote on 12 June, Carl I. Hagen realised that he could capitalise on it in more than one way. His immediate thoughts about the critical importance of the media are instructive; he had learned from his failure to capitalise on the 1974 debate about women's legal right to abortion right after he took over Anders Lange's ${ }^{6}$ seat in the parliament:

Again the attention would be on the Progress Party's position on an important issue, and we could use the situation to get publicity and to get our message out to the voters. I had had an equally good opportunity to promote the Progress Party on the abortion issue when I entered the Storting in 1974, but back then I was too inexperienced. I blew the entire opportunity by going public with my position way 
too early. Back then I didn't understand that the attention would have increased if I hadn't revealed it until a few days later. I would not make that mistake this time. (Hagen, 2007: 124 [Author's translation])

A week before the parliamentary vote, Hagen told his wife, who was his secretary: "We have to handle this so that the decision is made at the very last minute" (Iversen, 1998: 100 [Author's translation]).

Hagen devised a two-pronged plan to accomplish his goal(s), and he would execute it in public. First, he had to win over public opinion by framing the matter in terms of preferential treatment of farmers in the midst of financial distress, when everyone else was expected to show restraint. His argument would be that the farmers also had to show moderation. The public debate could not be about picking a government. Hagen (2007: 125 [Author's translation]) writes in his memoir that "I had to steer the debate through the media and the public sphere, so that people understood that this was what the issue was actually about, and not who was going to be prime minister in Norway". He stayed on message in his media appearances in the days leading up to the parliament's scheduled debate and vote on the matter.

Second, by his own admission, he decided to slow down the entire process (Hagen, 2007: 125), which he did by engaging the entire Progress Party apparatus and the prospective new prime minister, Conservative Party leader Rolf Presthus, in a public deliberation process. This served multiple purposes. To begin, the internal Progress Party deliberations looked like a textbook example of internal party democracy in action, in which the high command of the party sought input from and listened to its grass roots and activists about how the party should vote. Hagen would thus accrue internal and external democratic legitimacy. Put differently, it would make him and the party look good. Moreover, the internal process had the added benefit of reinforcing the activists' personal loyalty to him, as they would feel that they had been listened to (Moen, 2006: 159). Hagen therefore asked for statements from the party's province leaders and local and provincial branches. The party's parliamentary group held an open public hearing, where people living near Oslo were invited to attend the discussion, and the party's national board was convened to give advice. He sent Presthus a public letter containing ten questions about what a change in government would mean policy-wise for the Progress Party, which was dubbed "Presthus's 10 Exam Questions" by the media. Meanwhile, Presthus was kept in the dark about how Hagen would vote. Most dramatically, Hagen staged a TV event together with the leader of the Progress Party's youth organisation, Tor Mikkel Wara. Live on NBC's main evening newscast (Dagsrevyen), two days before the party would decide, Wara informed Hagen of the resolution passed by the youth party: if the proposal of the Conservative Party, the Christian Democrats and the Centre Party meant a wage increase for the farmers that was greater than the increase that others had got, the Progress Party should vote against a change in government (Hagen, 2007: 125-126 [Author's translation]). Hagen writes that the message "was communicated directly to the voters watching television at home, just like I wanted".

Hagen's grand finale came on 11 June, the night before the Storting would vote, after having kept the media and political Norway in suspense for a week (Iversen, 1998; Moen, 2006; Rommetvedt, 2014; Hagen, 2007). Hagen announced a press conference at 
19:30 in the Storting - the exact same time that the NBC's main evening television newscast began. He figured that given the high stakes - the government could be thrown out by the parliament the next day - NBC would cover his press conference live. At 19:15, Hagen dropped by Presthus's office and informed him of his decision, and proceeded to the room where he would hold the conference, where nearly 100 press journalists had gathered (Storsletten, 1987). As predicted, the NBC carried the event live, and agreed to let Hagen speak for three minutes before it could ask any questions. ${ }^{7}$ In prime time, with a TV audience of one million - one fourth of the population - and with Centre Party leader Johan J. Jacobsen standing by in the NBC's Oslo studio, waiting to comment on Hagen's decision, Hagen looked straight into the camera and explained that for the sake of the national economy, he would vote against the no-confidence motion. There would be no change in government (Hagen, 2007; Iversen, 1998; Moen, 2006; Rommetvedt, 2014).

\section{Goal attainment}

Hagen achieved both a major political and a major personal goal with his handling of the political and media opportunity that arose with the centre-right coalition's no-confidence motion. Politically, his fledgling party earned some much-needed external credibility as a serious and responsible actor that was capable of acting in the national interest, not only in terms of policy, but also by contributing to government stability. Hagen's decision a year earlier to vote against the centre-right coalition government over an increase in the gas tax, which led to its resignation, in spite of Hagen's 1985 campaign promise to support the government, had created a public perception of him as an opportunistic populist. The vote over the subventions to the farmers was an opportunity to transform his image. In his memoir, Hagen (2007: 128 [Author's translation]) states that 'I'm proud that we managed to put national interest ahead of the narrow partisan interest". To be sure, his ability to block an increase in the subventions to the farmers was a partisan interest, and in that sense he also won a significant policy victory. Moreover, the enormous publicity he received was to the benefit of the Progress Party. The quote above shows that these partisan considerations motivated Hagen. However, by doing what was widely seen as the fiscally most responsible thing by stressing the need for restraint and moderation, Hagen and his party looked responsible. That, of course, was also in his party's interest. But he could have voted for the government alternative that he clearly favoured, as evidenced by his vote for the recent no-confidence motions against the Labour Party government, and thus potentially have won considerable political concessions. Moreover, his no-vote exacerbated his already complicated relations with the centre-right parties, which in turn was unhelpful to his own chances of entering into a coalition government with them at some point. While Hagen's machinations were opportunistic and selfserving, he at least appeared willing and able to rise above hardball partisan politics at a critical moment for the country.

The entire episode also elevated Hagen personally as a major national political figure. He received widespread praise from both political opponents and the media for his handling of the matter, thus earning personal credibility, too. The ambitious Hagen, who wanted to grow and turn the Progress Party into a ruling party, showed himself to be a shrewd and savvy parliamentary tactician by making himself the most critical actor, and 
in the eyes of some, a statesman. The tabloid Dagbladet described Hagen's performance as "somewhat of a statesman's act", and the historian and prominent Socialist Left Party politician Trygve Bull even called him "the greatest statesman since Count Wedel"8 (Moen, 2006: 163 [Author's translation]). The prominent political science professor Jens A. Christophersen said that Hagen was the one "who has mobilised the national sense of responsibility" (Erlandsen, 1987 [Author's translation]). According to Progress Party biographer Jan Martin Iversen (1998: 101 [Author's translation]), Hagen had appeared the way he wanted to: "Statesman-like, powerful, solemn, and responsible". This observation is supported by Johansen (2002: 68), who much later argued that through the years, Hagen has embraced the role of the statesman in his TV appearances, noting that Hagen has often stared straight into the camera in the way that only the Norwegian king and the prime minister do when they give their televised New Year's speech.

Hagen was also crowned the country's most media-savvy politician. Aftenposten, the leading national broadsheet, referred to Hagen's "week-long political 'show" (Malmø, 1987 [Author's translation]). Norway's largest newspaper, VG, devoted a full page to the TV performance itself, which it called "a sparkling performance that gets an A for execution and style". Referring to him as "TV Hagen", it called him "the country's most media-aware politician", and quoted NBC employees saying that "many politicians have a lot to learn from Hagen when it comes to performing" (Storsletten, 1987 [Author's translation]). According to Iversen (1998: 101 [Author's translation]), "the term 'media politician' got a new meaning". Nearly three decades later, Hagen himself was no less effusive, stating that "I ruled the media for an entire week" (Rommetvedt, 2014 [Author's translation]). He conceded in his memoir that "I've kept many of them [newspaper clippings], and when I've felt down and frustrated, I've taken a look at them again. It cheers me up every time" (Hagen, 2007: 128 [Author's translation]).

\section{Conclusion}

Two conclusions follow from this analysis. First, one of populist leaders' most critical assets is their keen understanding of media logic. It enables them to recognise opportunities in their political and media environments, and to apply the appropriate means in pursuit of their goals. Consequently, it increases the likelihood of populist leaders having a crowning moment. Notably, their media-savviness can be used to transcend their populist image policy-wise, and the crowning moment can make populists appear less "anti-establishment", in that it turns the populist into a leading actor within the system he/she criticises.

Second, a crowning moment can have a long-term impact. In Hagen's case, it was followed by many political successes, including a breakthrough in the local elections later in 1987, and a national breakthrough in 1989. While successful mobilisation on the immigration issue in 1987 likely explains most of that success, it was Hagen's handling of the no-confidence motion months earlier that broadened his image. It was here that Hagen discovered his winning formula: populist, yet responsible when necessary. The Progress Party has managed to become a governing party while retaining its populist appeal.

Not all populists are equally media-savvy, and crowning moments can be cancelled out by future missteps. Moreover, crowning moments might be more elusive in a more 
complex media landscape, particularly in the age of social media. Future research should study the presence or absence of crowning moments in other contexts, in particular the impact of social media on populists' chances for a breakout moment.

\section{Funding}

This research was jointly supported by Norways Research Council and the University of Bergen.

\section{Notes}

1. Page 4 in the stand-alone copy of the chapter which the author received from Toril Aalberg, 10 April 2018.

2. Translation by Hjarvard (2018: 106).

3. The Progress Party campaigned against immigration for the first time in the 1987 election, but Hagen has publicly expressed anti-Islam views since the late 1970s (Hagen, 1979).

4. The party re-entered the parliament in 1981, after losing the four seats it won in 1973 and 1977.

5. The monopoly lasted until 1992.

6. Lange died in 1974.

7. Hagen and NBC later disagreed about how explicit their agreement that he would talk first had been (Bratholm, 2008). NBC argued that they had just agreed that he would be interviewed at the beginning of the newscast.

8. Count Herman Wedel Jarlsberg was a leading Norwegian politician in the 1800 s, who served as the president of the parliament and the first Norwegian governor of the Norwegian-Swedish union (18141905) (Britannica, 2018).

\section{References}

Asp, K. (1986). Mäktiga massmedier: Studier i politisk opinionsbildning [Powerful mass media: Studies in political opinion-building]. Stockholm: Akademilitteratur.

Boczkowski, P. \& Papacharissi, Z. (2018). Trump and the media. Cambridge: MIT Press.

Blumenthal, S. (1982). The permanent campaign. New York: Simon and Schuster.

Blumler, J. \& Kavanagh, D. (1999). The third age of political communication: Influences and features. Political Communication, 16(3): 209-230.

Bratholm, E. (2008). NRK forhandlet ikke med Hagen [The NBC did not negotiate with Hagen]. [online]. Retrieved from $<$ https://journalisten.no/story/52813>. [Accessed 2018, November 12].

Britannica. (2018). Count Herman Wedel-Jarlsberg. [online]. Retrieved from $<$ https://www.britannica.com/ biography/Johan-Caspar-Herman-Landgreve-Wedel-Jarlsberg>. [Accessed 2018, October 25].

Canovan, M. (1999). Trust the people! Populism and the two faces of democracy. Political Studies, 47(1): 2-16.

Capoccia, G. (2016). Critical junctures. In O. Fioretos, T. Falleti \& A. Sheingate (eds.), The Oxford handbook of historical institutionalism (pp. 89-106). Oxford: Oxford University Press.

Collier, D. \& Mahon, J. (1993). Conceptual stretching revisited - Adapting categories in comparative-analysis. American Political Science Review, 87(4): 845-855.

Edwards, G. (2012). Overreach: Leadership in the Obama presidency. Princeton: Princeton University Press. Erlandsen, H. C. (1987). Dype klassiske skilleliner [Deep traditional cleavages]. Aftenposten, 13 June, 1987.

Esser, F., Stępińska, A. \& Hopmann, D. N. (2017). Populism and the media: Cross-national findings and perspectives. In T. Aalberg, F. Esser, C. Reinemann, J. Stömback, \& C. de Vreese (eds.), Populist political communication in Europe (pp. 1-13). London: Routledge.

Farrell, D. (2006). Political parties in a changing campaign environment. In R. S. Katz \& W. Crotty (eds.), Handbook of party politics (pp. 122-133). London: SAGE Publications.

Freeden, M. (1998). Is nationalism a distinct ideology? Political Studies, 46(4): 748-765.

Gidron, N. \& Bonikowski, B. (2013). Varieties of populism: Literature review and research agenda. Working Paper Series. Cambridge, MA.,: Harvard.

Giugni, M. (2009). Political opportunities: From Tilly to Tilly. Swiss Political Science Review, 15(2): 361-367.

Goertz, G. (2006). Social science concepts: A user's guide. Princeton: Princeton University Press.

Hagen, C. I. (1979). Ingen moske i Oslo [No mosque in Oslo]. Aftenposten, 28. November, 1979. 
Hagen, C. I. (2007). Ærlig talt: memoarer 1944-2007 [Honestly speaking: Memoirs 1944-2007]. Oslo: Cappelen.

Harmel, R., Svåsand, L. \& Mjelde, H. (2018). Institutionalization (and de-institutionalization) of rightwing protest parties: The progress parties of Denmark and Norway. Colchester: ECPR Press.

Heinisch, R. (2003). Success in opposition - failure in government: Explaining the performance of right-wing populist parties in public office. West European Politics, 26(3): 91-130.

Herbst, S. (2003). Political authority in a mediated age. Theory and Society, 32(4): 481-503.

Hjarvard, S. (2008). The mediatization of society. Nordicom Review, 29(2): 105-134.

Iversen, J. M. (1998). Fra Anders Lange til Carl. I Hagen: 25 år med Fremskrittspartiet [From Anders Lange to Carl. I Hagen: 25 years with the Progress Party]. Oslo: Millennium.

Jagers, J. \& Walgrave, S. (2007). Populism as political communication style: An empirical study of political parties' discourse in Belgium. European Journal of Political Research, 46(3): 319-345.

Johansen, A. (2002). Talerens troverdighet [The credibility of the speaker]. Oslo: Universitetsforlaget.

Jungar, A-C. \& Jupskås, A. (2014). Populist radical right parties in the Nordic egion: A new and distinct party family? Scandinavian Political Studies, 37(3): 27-56.

Jupskås, A. (2015). Persistence of populism the Norwegian Progress Party, 1973-2009. Oslo: University of Oslo.

Kjeldsen, J. (2002). Den norske demagogen. Frykten for Carl I. Hagens retorikk [The Norwegian demagogue. The fear of Carl I. Hagen's rhetoric]. In M. Eide (ed.), Skråblikk. Medievitenskapelige formidlingsfrukter [ideomatic/untranslatable] (pp. 137-156). Bergen: Institutt for medievitenskap.

Lundby, K. (2009). Mediatization: Concept, changes, consequences. New York: Peter Lang Inc.

Malmø, M. (1987). Til Berlevåg og Bulgaria [To Berlevåg and Bulgaria]. Aftenposten, 13. June, 1987.

Manucci, L. (2017). Populism and the media. In C. R. Kaltwasser, P. Taggart, P. Ochoa Espejo, \& P. Ostiguy (eds.), The Oxford handbook of populism (pp. 467-488). Oxford: Oxford University Press.

Mazzoleni, G. (2008). Populism and the media. In D. Albertazzi \& D. McDonnell (eds.), Twenty-first century populism. The spectre of Western European democracy (pp. 49-64). Basingstoke: Palgrave Macmillan.

Mazzoleni, G. (2014). Mediatization and political populism. In F. Esser \& J. Strömbäck, (eds.), Mediatization of politics: Understanding the transformation of Western democracies (pp. 42-56). Basingstoke: Palgrave Macmillan.

Moen, E. S.(2006). Profet $i$ eget land [Profet in one's own country]. Oslo: Gyldendal.

Mudde, C. (2004). The populist zeitgeist: Government and Opposition, 39 (4): 541-563.

Mudde, C. (2007). Populist radical right parties in Europe. Cambridge: Cambridge University Press.

Pedersen, M. (1982). Towards a new typology of party lifespans and minor parties. Scandinavian Political Studies, 5(1): 1-16.

Rommetvedt, H. (2014). Hagen styrte ARK, men hvem styrte Hagen? [Hagen steered the ARK, but who steered Hagen?], Dagbladet, 6 May, 2014 [online]. Retrieved from < https:/www.dagbladet.no/kultur/ hagen-styrte-ark-men-hvem-styrte-hagen/60208556>. [Accessed 2018, November 12].

Sandnes, S. \& Tørdal, R. (2018). Monopoloppløsning på 1980-tallet [Dissolution of the monopoly in the 1980s]. [online]. Retrieved from $<$ https://ndla.no/nb/node/76666?fag=52222>. [Accessed 2018, October, 23].

Sartori, G.(1970). Concept misinformation in comparative politics. American Political Science Review, 64(4):1033-1053.

Semetko, H. (2006). Parties in the media age. In R. S. Katz \& W. Crotty (eds.), Handbook of party politics (pp. 515-527). London: SAGE Publications.

Storsletten, K. (1987). TV-Hagen slår til [TV-Hagen strikes]. VG, 12 June, 1987.

Strömbäck, J. \& Esser, F. (2014). Mediatization of politics: Towards a theoretical framework. In F. Esser \& J. Strömbäck (eds.), Mediatization of politics: Understanding the transformation of Western democracies (pp. 3-28). Basingstoke: Palgrave Macmillan.

Svåsand, L. (2002). The Norwegian Progress Party: A populist party? Paper presented at the conference Contemporary Populisms in Historical Perspective, 7-10 January 2003, at Liguria Center, Bogliasco, Genoa.

Thomas, D. (2006). A general inductive approach for analyzing qualitative evaluation data. American Journal of Evaluation, 27(2): 237-246.

Todal, P. (2003). Sosialistisk Venstreparti: Kunsten å vere seg sjølv [The Socialist Left Party: The art of being oneself ]. Dag og Tid, 3 May, 2003.

Wiesendahl, E. (2009). Die Mitgliederparteien zwischen Unmodernität und wieder endecktem Nutzen [Membership parties between outdatedness and rediscovered usefulness]. In U. Jun, O. Niedermayer \& E. Wiesendahl (eds.), Zukunft der Mitgliederpartei [The future of the membership party] (pp. 31-52). Opladen \& Farmington Hills, MI: Verlag Barbara Budrich.

Zaslove, A. (2008). Here to stay? Populism as a new party type. European Review, 16(3): 319-336. 